\title{
Methods and Devices for Registration of Road Microprofiles
}

\author{
ALEKSANDAR D. SKULIĆ, Polytechnic School of \\ Vocational Studies - Uroševac, Leposavic \\ BRANKO B. PEJOVIĆ, University of Pristina, \\ Faculty of Technical Sciences, Kosovska Mitrovica \\ TOMISLAV N. TODIĆ, University of Pristina, \\ Faculty of Technical Sciences, Kosovska Mitrovica \\ IVICA R. ČAMAGIĆ, University of Pristina, \\ Faculty of Technical Sciences, Kosovska Mitrovica \\ VLADAN M. MIĆIĆ, University of East Sarajevo, \\ Faculty of Technology, Bosnia and Herzegovina
}

\begin{abstract}
The vehicle presents a dynamic system performing vibrations under the influence of certain stimulus. Information driver receives from the environment and the vehicle is: macro and micro texture of the road, vibrations and noise of the vehicle's subsystem and so on. The road is usually evaluated according to its macro and micro texture. Microroughness of the roads is of great importance for the study of vehicle's oscillatory movements, reliable computation of vehicle systems, safety etc. Therefore, a special attention must be given to them during the analysis of dynamics, strength and safety of the vehicle. Microroughness that characterize the microprofile of the road in longitudinal and transverse direction have random character and can be established by experimental study of the road with utilization of devices. Accordingly, a variety of devices have been developed for measurement of macro-and micro profiles of the road as well as numerous mathematical and experimental procedures, which with certain approximation satisfy the given requirements, and with the increasing use of computer technology.
\end{abstract}

Key words: microprofile of the road, macrotexture, microtexture, methods of measurement, measurement devices

\section{INTRODUCTION}

The movements of the vehicle subsystems are conditioned, primarily, by the shape and size of the roughness, as the external factor and oscillatory-inertial characteristics, torque and the speed of the vehicle, as phenomena related to the vehicle itself. Based on that, it can be concluded that thorough research and defining of characteristics of microroughness of the road on which the vehicles moves, both in terms of periodicity characteristics, and in terms of energy level, elaboration and automation of the processes for measurement of roughness and mathematical apparatus for processing of obtained results, contribute to reliability, optimality and safety of the structure of the vehicle [1].

Author's address: Aleksandar Skulić, Polytechnic School of Vocational Studies, Uroševac, Leposavic, 24. novembra bb

Paper received: 13.01 .2016$.

Paper accepted: 26.05.2016.
Figure 1 presents the micro surface texture of the road.

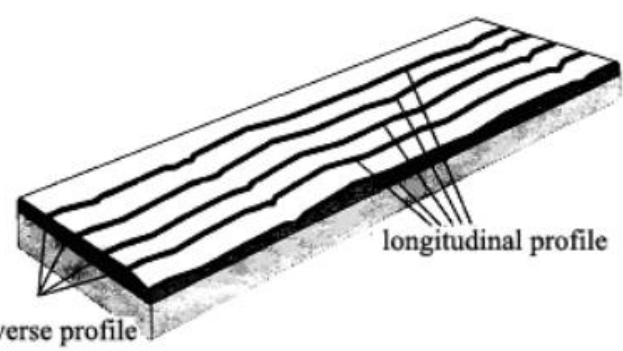

Figure 1 - Micro-texture in the function of the length and width of the road

The figure shows that microtexture of the road changes both along length and width. In the literature, often are used terms transverse and longitudinal profile $[2,3]$, which is shown in Figure 2 (a-longitudinal, btransverse).

Microprofile of the road belongs to a group of random processes [2], so it is necessary to determine 
the statistical parameters of the same. Microprofile of the road is identified on the basis of microroughness being measured with the use of special devices.
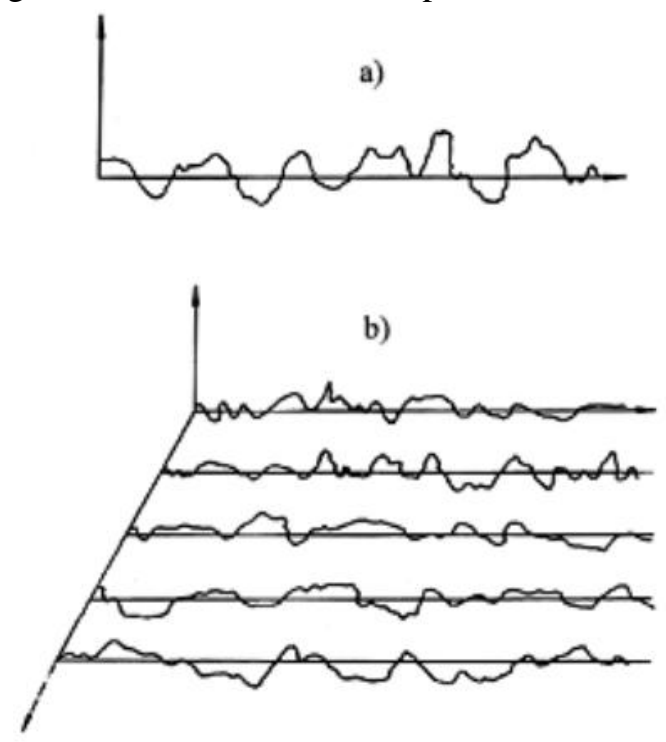

Figure 2 - Definition of the longitudinal (a) and transverse (b) microtexture of the road

\section{DESCRIPTION OF DEVICES FOR REGISTRATION OF MICROPROFILES OF THE ROAD}

There is a great number of devices and procedures for measurement of the parameters of the microprofile of the road $[4,5]$. According to the rule, the longitudinal profile is registered, and transverse is identified according to the assembly of parallel longitudinal profiles.

Devices for registration of microprofiles of the road can be classified into two categories [5]:

- no oscillatory properties, and

- with oscillatory properties ( inertial).

In device with no oscillatory properties, the measurement of microroughness amplitudes is performed in regard to adopted reference line. Problem of registration of roughness of longer wavelengths is solved by application of beam or laser.

Automation of the processes for registration of roughness and utilization of special devices multiple accelerates the mentioned process. The use of wheels on special devices has enabled the continuous recording of amplitudes of microroughness of the road.

One of the first devices realized is in the shape of articulated vehicle [5] where the changes of characteristic angles between certain subsystems are registered (Figure 3).

At articulated device, in the case of smaller wavelengths, the number of wheels above and under the intermediate level will be equal, so the suitable connection can provide for initial point in the center of the upper frame of the device remains at approximately the same constant height. The disadvantage is that device provides good registration of wavelengths that are shorter than length of the given frame. Having this in mind, it is obvious that this concept of devices can not be emphasized as representative in the view of wider application.

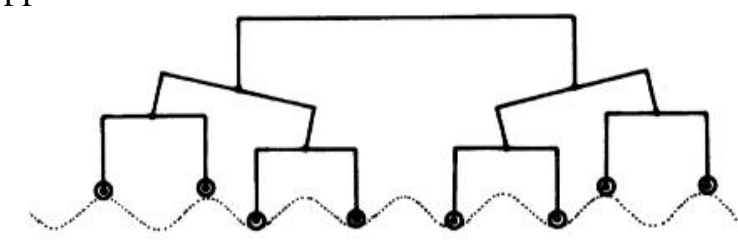

Figure 3 - Schematic layout of articulated device

Device for registration of acceleration of microroughness of the road is consisted of metal frame connected to traction vehicle on one end, and another one to the wheel. Better fitting of the wheel to the road surface is achieved by a spring connecting frame and traction vehicle. In the centre of the wheel is the acceleration pickup. In order to ensure verticality, the acceleration pickup is placed on a special, gyroscopic stabilized platform. The speed of wheel center movement on the road is determined by measuring the number of revolutions of the wheel. Since the measurement results depend on the radius of the wheel, the disadvantage of the device is reflected in the fact that the measurement results are influenced by flexibility and diameter of the wheel [6].

\subsection{Device developed in General Motors}

One of the most modern procedures for registration of microroughness of the road is developed by General Motors, Figure 4 [7-9]. The procedure simultaneously uses non-contact displacement pickup (laser, ultrasonic, radar) to register the movement from the certain point on the vehicle to the ground (usually on the roll axis), as well as the acceleration pickup for simultaneously registration of the acceleration of the same point on the vehicle. At the same time, the speed of the vehicle is also registered. Amplitudes of microroughness are calculated on the basis of two measured quantities (acceleration and movement), with the application of computers. This procedure has its advantages and disadvantages. The advantages of the procedure are: high speed of measurement, reproducibility of the result, the partial elimination of the influence of oscillatory parameters of the vehicle; the disadvantages are reflected in the presence of the measurement errors due to the change of spatial position of the vehicles during their movement, as well as the change of the position of roll axis with the change of the load of measuring vehicle $[8,9]$. 


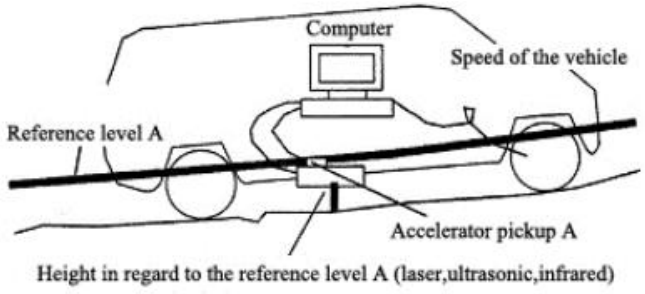

Figure 4 - The scheme of the device from General Motors

Collection and data processing for the purpose of calculation of real amplitudes of microroughness of the road must be conducted during the measurement ("on line"), while all other statistic calculation can be conducted later in the laboratory (in both cases the computer is used).

Transport and Road Research Laboratory in England has developed a completely different concept of profilometer that comprises instruments for measurement of acceleration [10]. Their laser profilometer is consisted of rigid beam along which the laser road sensors are placed, so during the measurement the continuous profile was developed. Monitoring the distance from the vehicle body to the road surface requires one sensor for each wheeltrack of the vehicle and one or two additional sensors for the depth of the microtexture. These sensors are mounted on the vehicle, as shown on Figure 5. It is preferred to conduct measurements of the roughness on the left and right side of the wheeltrack as well as in the centre of the traffic lane [11].

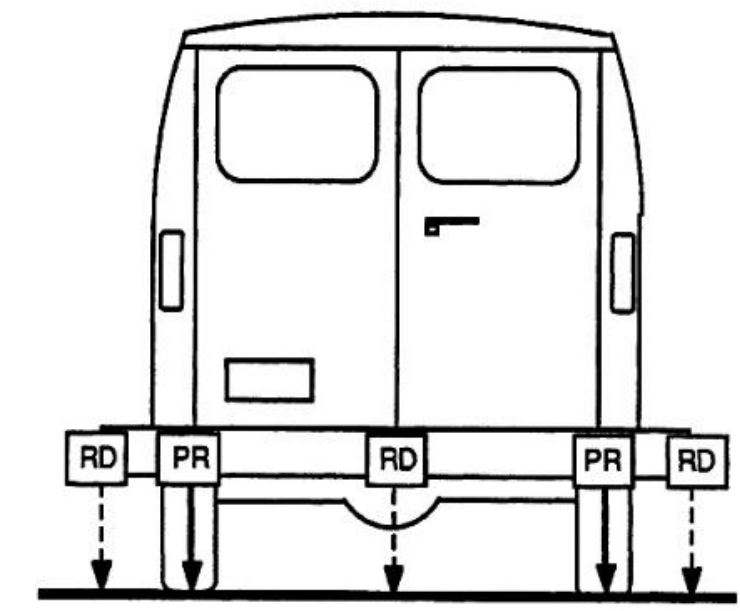

Figure 5 - Mounting of the noncontact road sensors

\subsection{Sensor measured microtexture depth}

Current laser microtexture measurement devices work by measuring the distance between the sensor and the road surface. As the sensor moves along the road, changes in the distance between the sensors and the road are recorded at short intervals (it is typically $1 \mathrm{~mm}$ ) [12]. In this way a detailed microtexture profile of the road surface is determined, but this data require further processing. Data processing usually involves the following steps:

- the data are collected on the shorter sections of the road $(100 \mathrm{~mm}-300 \mathrm{~mm})$ where the measurement of the microtexture was conducted;

- the data are filtered in order to avoid the unwanted effects on the content of the signal as is the change of the speed of the vehicle, change of the height between the sensors and the road surface due to vehicle oscillation, etc.

- the filtered data are further processed in order to obtain the result that characterizes the height of microtexture within the each observed section;

- the results for each observed section are aggregated for longer sections of the road (usually $10 \mathrm{~m}$ ) [12].

Microtexture depth measurements made by laser systems are known as Sensor Measured Microtexture Depth (SMTD). These measurements are conducted on the left and right wheeltrack as well as in the centre of the traffic lane. SMDT values are calculated according to following expression [8]:

$$
S M T D=\frac{n \Sigma Y^{2}-(\Sigma y)^{2}-\left\{12(\Sigma X Y)^{2}+P-\left(n^{2}-1\right)\right\}}{n^{2}}
$$

where:

$$
P=\frac{5\left\{\left(n^{2}-1\right) \sum Y-12\left(\Sigma X^{2} Y\right)^{2}\right\}}{4\left(n^{2}-4\right)}
$$

$n$ - number of measurements in a $300 \mathrm{~mm}$ length and is always forced to be add

$$
y \text { - laser height measurement }(\mathrm{mm}) \text {, }
$$

$x$-normal distance between the measurements $m m)$.

In order to obtain SMTD values the measurements are conducted on the determined road sections in short measurement intervals $(300 \mathrm{~mm} \pm 15 \mathrm{~mm}$ ). In addition, the obtained results are aggregated on the longer lengths in order to obtain the final road profile (Figure 6).

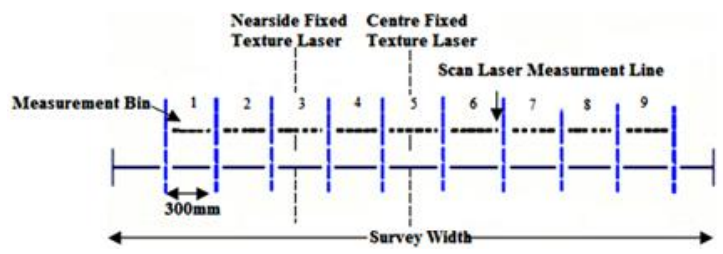

Figure 6 - Illustration of scanning laser and fixed laser measurement lines

In addition, current laser systems include the measurement of the mean profile depth (MPD), which is widely used in Europe [13]. The main difference between these two methods is the way the microtexture depth is evaluated: SMTD measure presents the mean 
square value of microtexture both beyond and under the average level, while MPD measures the height of the highest point beyond the average level. The relation between these measures depends on the type of the surface and shape of road microtexture, as presented on Figure 7, which compares two different shapes of surfaces with the same SMTD values.

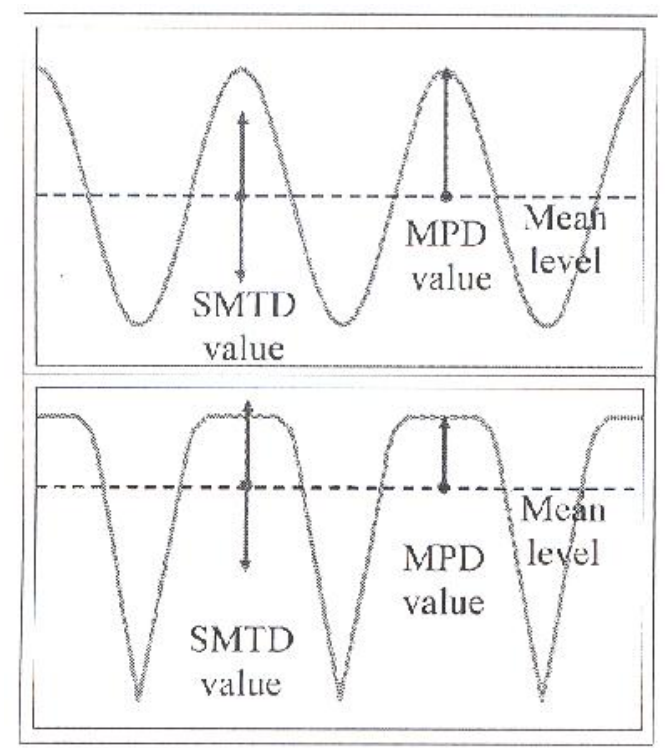

Figure 7 - Comparison of SMTD and MPD values for surfaces with different shapes

For the first surface MPD value is higher than SMTD value, while for the second surface MPD value is lower than SMTD value.

\subsection{Current laser systems}

Current laser systems are designed to collect video and laser measured data relating to the microtexture, profile and road geometry, and are used as reference devices for accreditation of the vehicles for the examination of road network. The description of such vehicle with all additional equipment is shown on Figure 8 [14-16].

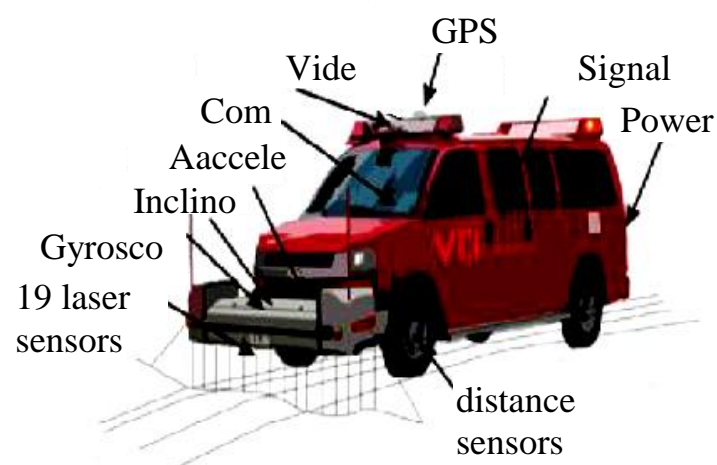

Figure 8 - Vehicle for examination of road network

As a concrete example we present HARRIS 2 laser system (The Highways Agency Road Research Information System) developed in Great Britain, as well as the results of the measurements obtained with this system [16].

HARRIS 1 laser system has two lasers for measurement of microtexture on the left, right and central part of the traffic lane, which operate at $64 \mathrm{kHz}$ and collect information on road surface in the intervals of $1 \mathrm{~mm}$. Results obtained in such way are further processed in order to obtain sensor measured microtexture depth (SMDT) and mean profile depth (MPD). The profile beam where the lasers are mounted is used for obtaining of final shape of road surface including the measurement of microtexture depth of the road. It is consisted of 25 lasers located in a way to measure the full width of the traffic lane [16].

\section{CONCLUSION}

During the movement, the vehicle and the vehicle users are influenced by the dynamic forces originating from the large number of dynamic simulators affecting the vehicle. The years of experience show that the mentioned dynamic excitations, that cause the spatial vibrations of the vehicles, deteriorate the properties of the vehicles and lead to the fatigue of the users and the vehicle structure, therefore the certain measures must be taken in order to reduce their influence.

Dominant external influences on the vehicle behaviors, that is, dominant oscillatory excitations during the movement of the vehicle are: road parameters, wheel nonuniformity, oscillatory excitations of the drive unit, dynamic excitations from vehicle transmission and aerodynamic excitations. All oscillatory excitations that influences the movement of the vehicle are interconnected, that is, conjugated and interact to each other. Increase or decrease of the intensity of one excitation directly or indirectly affects the intensity and character of other excitations such forming the dynamic system inside the system of driver-vehicle-environment. From the engineering point of view, it is very important to measure the contribution of each oscillatory excitation as well as the mathematical interpretation of their excitation effect and interaction with the motor vehicle.

In order to protect the vehicle and the users from the negative effects produced by mentioned dynamic forces and their reduction to acceptable boundaries, it is necessary to pay a special attention to fundamental systems that protect vehicle from dynamic forces and reduce them to acceptable boundaries (systems for supporting and guiding the wheels, pneumatics, seats, systems for elastic support of the cabin, system for elastic support of the driving group, etc.).

Motor vehicle as a dynamic system is closely related to the road, that is, to its macro and microprofile. Microroughness of the road belongs to a group of 
accidental processes and depends both on the road type and on transverse and longitudinal microprofile. Therefore, a numerous methods for registration of macro and microprofile of the road have been developed ( mainly based on GPS- Global Positioning System) from which the data necessary for the estimation of the quality of the roads can be obtained.

\section{REFERENCES}

[1] Demić M, Dynamic excitations of the car, Institute for Nuclear Sciences, "Vinča" Center for motors and vehicles, Belgrade, 2006.

[2] M. Demic, D. Diligenski, M. Demic, I. Demic, New design of a road profiler. International Journal of $\mathrm{Au}-$ tomotive Technology, Vol. 11, No. 6, pp. 801-808, 2010 .

[3] Tyan F, Hong Y. F, Tu S. H, \& Jeng W. S, Generation of random road profiles. Journal of Advanced Engineering, 4(2), 1373-1378, 2009.

[4] A. DeMarco and C. Stedman, "Automated GPS Mapping of Road Roughness," Bachelor thesis, Worcester Polytechnic Inst., USA, 2007.

[5] Demić M, Cybernetics system Man-Vehicle- Environment, Center for Scientific Research of SASA and and University in Kragujevac, Kragujevac, 2008.

[6] González A, O’brien E, J. Li Y. Y, \& Cashell K, The use of vehicle acceleration measurements to estimate road roughness. VehicleSystem Dynamics, 46(6), 483-499, 2008.

[7] Demić M, Pehan S, Kegl B, Supplement to the projection of the device for registration of microroughness of the road, Tehnika-Mašinstvo, 52(4-5), 2003.

[8] Imine H, Delanne Y, \& M'sirdi N. K, Road profile input estimation in vehicle dynamics simulation. Vehicle System Dynamics, 44(4), 285-303, 2006.
[9] Do T. M, \& Le T. C, Performance analysis offft filter to measure displacement signal in road roughness profiler. International Journal of Computer and Electrical Engineering, 5(4), 356, 2013.

[10]Mays C, Wright A, Furness G, Road surface texture inspection using high resolution transverse profile measurements, Unpublished project report upr /ie/100/06, August 2006.

[11]Loizos A, \& Plati, C, Evolutional process of pavement roughness evaluation benefiting from sensor technology. International Journal on Smart Sensing and Intelligent Systems, 1, 370-387, 2008.

[12]Viner H, Abbott P, Dunford A, Dhillon N, Parsley L, Read C, Surface texture measurement on local roads, Published project report, August 2006.

[13]Moldovanu A, \& Huang L, High Speed Road Texture Measurement Using Laser Displacement Sensors. IFAC Proceedings Volumes, 46(20), 530-533, 2013.

[14]Kertesz I, Lovas T, \& Barsi A, Measurement of road roughness by low-cost photogrammetric system. International Archives of Photogrammetry, Remote Sensing and Spatial Information Sciences, 36(5/C55), 4, 2007.

[15]Qader A, \& Ali J. H, High performance real-time embedded systems: design and implementation of road surface analyzer system, Ph.D. dissertation, Dept. Comput. Sci. and Eng, Univ. Texas at Arlington, USA, 2010.

[16]Still P. B. and Jordan P. G, Evaluation of the TRRL High-Speed Profilometer, TRRL Laboratory Report 922, Crowthorne, UK, 2008.

\section{REZIME}

\section{METODE I UREĐAJI ZA REGISTROVANJE MIKROPROFILA PUTA}

Vozilo predstavlja dinamički sistem koji vrši vibracije pod dejstvom odgovarajućih pobuda. Informacije koje vozač prima od okruženja i vozila mogu biti: makro i mikro-reljef puta, vibracije i buka podsistema vozila i sl. Put se obično ocenjuje na osnovu njegovog makro- i mikroreljefa. Mikroneravnine puteva su od velikog značaja za proučavanje oscilatornih kretanja vozila, pouzdan proračun sistema vozila, bezbednost i slično. Zbog toga im se pri analizama dinamike, čvrstoće i bezbednosti vozila mora posvetiti posebna pažnja. Mikroneravnine koje karakterišu mikroprofil puta u podužnom i poprečnom pravcu su slučajnog karaktera i mogu se ustanoviti eksperimentalnim istraživanjima puteva, uz korišćenje uređaja. Shodno tome razvijeni su mnogobrojni uređaji za merenje makro- i mikroprofila puta kao i mnogobrojni matematički i eksperimentalni postupci koji sa određenim aproksimacijama zadovoljavaju postavljene zahteve, sa sve većom upotrebom kompjuterske tehnike.

Ključne reči: mikroprofil puta, makroreljef, mikroreljef, metode merenja, uređaji za merenje 